$p$-ISSN 1693-9484, $e$-ISSN : 2621-8313

Majalah Ilmiah Bahari Jogja (MIBJ)

Vol. 17 No. 1, Februari 2019 (71-85)

DOI : $10.33489 /$ mibj.v17i1.200

(C) 2019 Akademi Maritim Yogyakarta

BAHARI JOG]A

\title{
Analisis Pengelolaan Sampah Di Kapal Dan Peran Awak Kapal Terhadap Pencegahan Pencemaran Laut Dari Kapal Di Pelabuhan Tanjung Perak Surabaya
}

\author{
Kuncowati $^{*}$ \\ ${ }^{1}$ Nautika, Program Diploma Pelayaran, Universitas Hang Tuah Surabaya , Jl.Arief \\ Rachman Hakim No.150,Surabaya \\ *Corresponding Author. E-mail : kuncowatiuht@gmail.com. Telp: 081225217371
}

\begin{abstract}
Abstrak
Dengan meningkatnya jumlah armada kapal pada pengangkutan melalui laut, berdampak pada lingkungan laut yaitu sampah yang dihasilkan dari kapal juga meningkat. Dalam kegiatan operasional kapal sehari - hari, menghasilkan sampah seperti sisa buangan rumah tangga dan dunnage yang sudah tidak terpakai yang terdiri atas plastik, kertas, besi, kaca, sisa makanan dan sampah lainnya. Apabila sampah ini masuk ke dalam laut maka akan berakibat laut akan tercemar dan fungsi laut akan menurun. Dalam Konvensi Internasional mengenai pencegahan pencemaran dari kapal MARPOL 1973 /1978 pada annex V tentang sampah (GARBAGE) mengatur ketentuan pembuangan sampah dari kapal, namun masih dijumpai pembuangan sampah oleh penumpang kapal maupun awak kapal di laut dengan jarak dan ketentuan yang tidak sesuai dengan MARPOL 1973/1978 Annex V. Oleh karena itu peneliti menganalisis Pengelolaan sampah di kapal yang dilakukan oleh kapal - kapal di Pelabuhan Tanjung Perak Surabaya sebagai upaya untuk mengurangi pencemaran laut. Metode penelitian yang digunakan adalah metode kuantitatif yaitu analisis regresi dengan menyebarkan angket terhadap 100 ( seratus ) responden awak kapal yang kapalnya sandar di Dermaga Tanjung Perak Surabaya. Dari hasil perhitungan regresi diperoleh faktor pengelolaan sampah di kapal berpengaruh terhadap peningkatan pencegahan pencemaran dari kapal sebesar $48,6 \%$ dan faktor peran awak kapal berpengaruh terhadap pencegahan pencemaran dari kapal sebesar 31,5\%.
\end{abstract}

Kata kunci : pengelolaan sampah di kapal, pencemaran laut dari sampah

\begin{abstract}
With the increase in the number of ships in the sea transport, the impact on the marine environment is that the waste produced from ships also increases. In daily ship operations, it produces garbage such as household waste and unused dunnage consisting of plastic, paper, iron, glass, food scraps and other rubbish. If this garbage enters the sea, the sea will be polluted and the marine function will decline. In the International Convention on the prevention of pollution from the 1973/1978 MARPOL vessel on the annex $V$ on waste (GARBAGE) regulating the disposal of garbage from ships, but still found garbage disposal by ship passengers and crew at sea with distance and provisions that are not in accordance with MARPOL 1973/1978 Annex V. Therefore, researchers analyzed the management of garbage on ships carried out by ships at the Port of Tanjung Perak Surabaya in an effort to reduce pens contamination of the sea. The research method used is the
\end{abstract}


quantitative method, namely regression analysis by distributing questionnaires to 100 (one hundred) respondents of crew members who ship at the Tanjung Perak Pier in Surabaya. From the results of the regression calculation, it is obtained that the waste management factor on the ship has an effect on increasing pollution prevention from ships by $48.6 \%$ and the role factor of the crew influences the prevention of pollution from ships by $31.5 \%$

Keywords: garbage management on ships, marine pollution from garbage

\section{PENDAHULUAN}

Dalam upaya memberdayakan Industri Pelayaran Nasional, Presiden Susilo Bambang Yudhoyono pada tahun 2005 mengeluarkan Instruksi Presiden No. 5 Tahun 2005 yaitu dengan menerapkan asas Cabotage dimana muatan dalam negeri wajib diangkut oleh kapal - kapal berbendera Indonesia. Manfaat yang diperoleh dengan diberlakukannya azas cabotoge adalah jumlah armada kapal yang semakin meningkat. Meningkatnya jumlah kapal juga di dukung pula oleh Presiden Joko Widodo pada pidato di Konferensi Tingkat Tinggi ( KTT ) tanggal 13 November tahun 2014 di Myanmar dengan penegasan bahwa Indonesia sebagai poros maritim dunia. Dengan meningkatnya jumlah armada kapal pada pengangkutan melalui laut, ini berdampak pada lingkungan laut yaitu sampah yang dihasilkan dari kapal juga meningkat. Dalam kegiatan operasional kapal sehari - hari tentunya menghasilkan sampah seperti sisa buangan rumah tangga seperti plastik, kertas, besi, kaca, sisa makanan dan sampah lainnya. Apabila sampah ini masuk ke dalam laut maka akan berakibat laut akan tercemar dan akan menurun fungsi laut tersebut serta berakibat yang tidak baik terhadap masyarakat sekitar. Dalam Konvensi Internasional mengenai pencegahan pencemaran dari kapal 1973 protokol 1978 pada annex V tentang sampah (GARBAGE). Konvensi Internasional tentang pencegahan pencemaran dari kapal 1973 yang diperbaharui melarang pembuangan sampah plastik ke laut termasuk kantong sampah yang terbuat dari plastik, tali sintetis, dan jaring sintetis. Sampah makanan dan sampah lainnya tidak boleh dibuang di laut dalam jarak hingga 12 mil dari daratan, kecuali jika telah digiling dan dapat menembus saringan dengan kisi - kisi tidak lebih dari $25 \mathrm{~mm}$. Dalam jarak 3 mil dari darat, sampah, walaupun telah digiling dilarang dibuang ke laut. Dalam jarak 25 mil dari daratan, pembuangan dunnage (terap), bahan lapisan dan pembungkus yang dapat mengapung tidak diperbolehkan. Tetapi walaupun merupakan terdapat ketentuan pembuangan sampah dalam MARPOL 1973/1978 namun masih dijumpai pembuangan sampah oleh penumpang kapal maupun awak kapal di laut dengan jarak dan ketentuan yang tidak sesuai dengan MARPOL 1973/1978 Annex V. Oleh karena itu peneliti akan menganalisis Pengelolaan sampah di kapal yang dilakukan oleh kapal - kapal di Pelabuhan Tanjung Perak Surabaya sebagai upaya untuk mengurangi pencemaran laut. 


\section{Penelitian Terdahulu}

Penelitian terdahulu berguna untuk memperkaya teori yang digunakan untuk mengkaji penelitian yang dilakukan, sedangkan penelitian yang dijadikan perbandingan pada penelitian ini tidak terlepas dari topik penelitian yaitu mengenai Pengelolaan sampah di kapal dan peran awak kapal untuk mencegah pencemaran di laut.Perbandingan dengan penelitian terdahulu dapat dilihat seperti berikut pada tabel di bawah ini :

Tabel 1. Perbandingan Penelitian Terdahulu

\begin{tabular}{|c|c|c|c|}
\hline $\begin{array}{l}\text { Nama } \\
\text { Peneliti }\end{array}$ & udul & Tetode & asil penelitian Penelitian \\
\hline $\begin{array}{l}\text { Purwaning } \\
\text { sih,Wiwik, } \\
2007\end{array}$ & $\begin{array}{l}\text { Strategi } \\
\text { pengelolaan } \\
\text { Sampah } \\
\text { dalam kapal } \\
\text { penumpang } \\
\text { tipe PAX } \\
2000\end{array}$ & $\begin{array}{l}\text { Pengamata, } \\
\text { interview, } \\
\text { analisa } \\
\text { kalori } \\
\text { sampah } \\
\text { dengan } \\
\text { metode } \\
\text { bomb- } \\
\text { calorimeter }\end{array}$ & $\begin{array}{l}\text { Strategi pengelolaan dilakukan } \\
\text { dengan membuat suatu standar } \\
\text { operasional prosedur SOP yang } \\
\text { menjadi petunjuk pelaksanaan tugas } \\
\text { pengelolaan sampah dalam kapal } \\
\text { penumpang sehari-hari. Dari data- } \\
\text { data dan analisa serta pembahasan } \\
\text { yang dilakukan didapat suatu hasil } \\
\text { yang menyatakan bahwa strategi } \\
\text { pengelolaan sampah yang dibuat } \\
\text { akan bisa mereduksi kuantitas } \\
\text { sampah dari kapal yang dibuang ke } \\
\text { darat sebesar 5455 dari seluruh } \\
\text { kuantitas sampah kapal penumpang } \\
\text { tipe PAX 2000. Strategi pengelolaan } \\
\text { menghasikan suatu koordinasi tugas } \\
\text { yang lebih baik dan bisa } \\
\text { mengefisienkan biaya pengelolaan } \\
\text { sebesar 3526. }\end{array}$ \\
\hline $\begin{array}{l}\text { Nina } \\
\text { Nurhasana } \\
\text { h,Asmar } \\
\text { jhoni,Nur } \\
\text { shabrina,2 } \\
016\end{array}$ & $\begin{array}{l}\text { Persepsi crew } \\
\text { dan } \\
\text { manjemen } \\
\text { dalam } \\
\text { penerapan } \\
\text { ISM Code } \\
\text { bagi } \\
\text { keselamatan } \\
\text { Pelayaran dan } \\
\text { Perlindungan } \\
\text { Lingkungan }\end{array}$ & $\begin{array}{l}\text { Studi kasus } \\
\text { dan } \\
\text { deskriptif }\end{array}$ & $\begin{array}{l}\text { Pada manajemen kapal, seharusnya } \\
\text { secara periodik melakukan pelatihan } \\
\text { terhadap penanggulangan dan } \\
\text { pencegahan gangguan keselamatan } \\
\text { terhadap aktivitas pelayaran dari } \\
\text { Perusahaan Pelayaran yang } \\
\text { bersangkutan. } \\
\text { menanggulangi dan mencegah } \\
\text { keselamatan, Perusahaan Pelayaran } \\
\text { harus memiliki fasilitas dan } \\
\text { peralatan sesuai dengan ketentuan } \\
\text { ISM Code }\end{array}$ \\
\hline $\begin{array}{l}\text { Mirdin } \\
\text { Ahmad,20 } \\
16\end{array}$ & $\begin{array}{l}\text { Analisis } \\
\text { Penanganan } \\
\text { sampah di } \\
\text { kapal untuk }\end{array}$ & $\mathrm{K}$ & $\begin{array}{l}\text { (1) pencemaran laut yang } \\
\text { disebabkan oleh awak kapal tidak } \\
\text { memahami prosedur penanganan } \\
\text { limbah kapal sesuai aturan }\end{array}$ \\
\hline
\end{tabular}

Majalah Ilmiah Bahari Jogja 73 | http://jurnal.amy.ac.id/index.php/MIBJ/ 


\begin{tabular}{|l|l|l|}
\hline $\begin{array}{l}\text { mencegah } \\
\text { polusi laut }\end{array}$ & $\begin{array}{l}\text { MARPOL Annex V; (2) } \\
\text { Penanganan sampah plastik dan sisa } \\
\end{array}$ & $\begin{array}{l}\text { makanan yang dilakukan oleh awak } \\
\text { kapal pada kapal tidak memenuhi } \\
\text { persyaratan yang ditentukan dalam } \\
\text { aturan MARPOL Annex V. }\end{array}$ \\
\hline
\end{tabular}

Sumber : Hasil kajian penulis, 2018

Dari hasil penelitian yang dilakukan oleh Purwaningsih, Wiwik (2007), Strategi pengelolaan dilakukan dengan membuat suatu standar operasional prosedur SOP yang menjadi petunjuk pelaksanaan tugas pengelolaan sampah dalam kapal penumpang sehari-hari. Dari data-data dan analisa serta pembahasan yang dilakukan didapat suatu hasil yang menyatakan bahwa strategi pengelolaan sampah yang dibuat akan bisa mereduksi kuantitas sampah dari kapal yang dibuang ke darat sebesar 5455 dari seluruh kuantitas sampah kapal penumpang tipe PAX 2000. Strategi pengelolaan menghasikan suatu koordinasi tugas yang lebih baik dan bisa mengefisienkan biaya pengelolaan sebesar 3526 .

Hasil penelitian yang dilakukan oleh Nina Nurhasanah,Asmar jhoni,Nur shabrina,( 2016 ) adalah Pada manajemen kapal, seharusnya secara periodik melakukan pelatihan terhadap penanggulangan dan pencegahan gangguan keselamatan terhadap aktivitas pelayaran dari Perusahaan Pelayaran yang bersangkutan. Untuk menanggulangi dan mencegah keselamatan, Perusahaan Pelayaran harus memiliki fasilitas dan peralatan sesuai dengan ketentuan ISM Code.

Penelitian yang dilakukan Mirdin Ahmad, (2016) mendapatkan hasil bahwa (1) pencemaran laut yang disebabkan oleh awak kapal tidak memahami prosedur penanganan limbah kapal sesuai aturan MARPOL Annex V; (2) Penanganan sampah plastik dan sisa makanan yang dilakukan oleh awak kapal pada kapal tidak memenuhi persyaratan yang ditentukan dalam aturan MARPOL Annex V.

Dalam penelitian ini Penulis menganalisis pengelolaan sampah di kapal dan peran awak kapal dalam pencegahan pencemaran di kapal dari sampah di Pelabuhan Tanjung Perak Surabaya karena masih dijumpai masih ada penumpang atau awak kapal yang membuang sampah tidak sesuai ketentuan Annex V Marpol 1973/1978 dengan metode analisa secara kuantitatif, perbedaan antara penelitian yang dilakukan penulis dalam penelitian ini dengan Mirdin Ahmad (2016) adalah Mirdin Ahmad ( 2016 ) menggunakan metode kualitatif sedangkan penulis menggunakan metode analisis kuantitaf dan responden pada awak kapal yang kapalnya sandar diTanjung perak Surabaya.

\section{Pengeloaan sampah di kapal}

Pengelolaan adalah kegiatan pemanfaatan dan pengendalian atas semua sumber daya yang diperlukan untuk mencapai tujuan ataupun menyelesaikan tujuan tertentu ( Prajudi Atmosudirjo,1982). Menurut Sondang P.Siagian ( 1997), pengeloaan adalah soft skill / ketrampilan untuk mencapai suatu hasil tertentu dengan menggunakan tenaga / bantuan orang lain. Sedangkan menurut George R.Terry pengelolaan adalah pemanfaatan sumberdaya manusia ataupun 
sumberdaya manusia ataupun sumber daya lainnya yang dapat diwujudkan dalam kegiatan perencenaan, pengorganisasian, pengarahan dan pengawasan untuk mencapai tujuan tertentu.

Jadi Pengeloaan sampah di kapal adalah kegiatan pemanfaatan dan pengendalian atas semua sumber daya manusia dan lainnya yang ada untuk mencapai tujuan supaya sampah tidak mencemari laut sesuai ketentuan nasional dan Internasional.

Sampah menurut annex V MARPOL 1973/1978 adalah berarti semua sisa makanan, bahan - bahan buangan rumah tangga dan bahan - bahan buangan tidak termasuk ikan segar dan bagian daripadanya, pengoperasian kapal secara umum yang harus dibersihkan secara terus menerus atau secara periodik. Pelaksanaan regulasi 2 ( dua ) Marpol annex V 1973/1978 berlaku bagi semua kapal. Aturan dalam annex V MARPOL 1973/1978 menyebutkan bahwa:

a. Pembuangan ke laut dari semua jenis plastik, termasuk tali sintetis, jaring jaring penangkap ikan sintetis dan kantong - kantong sampah plastik dilarang

b. Pembuangan sampah ke laut dari sampah berikut harus dilaksanakan sejauh dapat di praktekkan dari dari daratan terdekat tetapi dalam beberapa keadaan dilarang bila jarak dari daratan terdekat kurang dari :

i. $25 \mathrm{Nm}$ dilarang membuang bahan - bahan pelapis dan bahan kemasan yang dapat mengapung

ii. $12 \mathrm{Nm}$ dilarang membuang sisa makanan dan semua jenis sampah termasuk produk kertas ,kaca, logam, botol - botol dan sampah yang serupa

c. Pembuangan ke laut sampah khusus sesuai paragraph ii dari regulasi ini harusnya diijinkan apabila sampah melalui pencacah atau penggiling sejauh dapat dipraktekkan dari daratan terdekat tetapi dalam beberapa keadaan dilarang jika jarak dari daratan terdekat kurang dari $3 \mathrm{Nm}$. Pencacah atau penggiling seperti itu. Pencacah atau penggiling seperti itu harus mampu melewati saringan tidak lebih dari $25 \mathrm{~mm}$.

Jika sampah bercampur dengan pembuangan yang lain maka peralatan yang lebih kuat harus digunakan. Persyraratan khusus untuk pembuangan sampah :

1. Pembuangan dari setiap material yang diatur oleh annex $V$ ini seharusnya dilarang dari platform ( anjungan ) tetap atau terapung yang bergabung dalam explorasi, exploitasi dan asosiasi pengeboran lepas pantai dari sumber daya mineral dan dari semua kapal yang sandar dalam radius 500 meter dari platform

2. Pembuangan ke laut dari sisa makanan seharusnya diijinkan jika telah melalui pencacah atau penggiling dari anjungan ( platform ) tetap atau terapung yang lokasinya lebih dari $12 \mathrm{Nm}$ dari daratan dan semua kapal saat sandar dalam radius 500 meter dari anjungan ( platform ) pencacah atau penggiling seperti itu harus melalui saringan tidak lebih dari $25 \mathrm{~mm}$

Pengecualian dalam regulasi 6 aturan Marpol 1973/1978 disebutkan bahwa peraturan dalam annex $\mathrm{V}$ tidak diberlakukan untuk :

1. Pembuangan sampah yang mendesak / penting dari kapal dengan alas an untuk keselamatan kapal dan keselamatan di laut. 
2. Sampah yang dihasilkan karena adanya kerusakan kapal atau pemasangan peralatan dengan alas an sebagai tindakan pencegahan yang dilakukan sebelum dan sesudah kejadian kerusakan untuk mencegah atau memperkecil kerusakan yang terjadi.

3. Kehilangan net/ jala - jala ikan yang dipasang dengan alasan untuk tindakan pencegahan yang dilakukan untuk terjadinya kehilangan yang lebih banyak.

Dalam regulasi 7 Annex V Marpol 1973/1978 tentang Fasilitas Penampungan menyebutkan bahwa pemerintah Negara yang tergabung dalam konvensi ini untuk meyakinkan penyediaan fasilitas penampungan sampah sampah tanpa menyebabkan keterlambatan kapal, dan sesuai dengan kepentingan dan yang digunakan oleh kapal.

Dalam regulasi 8 Annex V Marpol 1973/1978 tentang Port State Control menyebutkan bahwa pada waktu kapal berada di pelabuhan, pejabat dapat melakukan pemeriksaan di atas kapal terhadap nakhoda dan anak buah kapal, jika tidak mengetahui pencegahan polusi dari kapal dengan baik kapal tidak diijinkan untuk berlayar.

Dalam regulasi 9 Annex V Marpol 1973/1978 disebutkan bahwa

1. Setiap kapal dengan panjang seluruh 12 meter atau lebih harus memasang placard supaya anak buah kapal dan penumpang mengetahui persyratan pada peraturan 3 dan 5 aturan ini. Dengan bahasa kerja yang digunakan untuk personel kapal untuk kapal - kapal dengan pelayaran dari pelabuhan atau terminal offshore dengan ketentuan hukum yang berlaku dengan bahasa Inggris dan Perancis.

2. Setiap kapal dengan GRT 400 ton ke atas dengan jumlah awak kapal lebih dari 15 orang harus dilengkapi dengan Garbage Manajement Plans

3. Setiap kapal dengan GRT 400 ton lebih yang pelayaran dari pelabuhan ke terminal offshore di bawah hukum yang berlaku dan platform /rig tetap dan mengapung yang melakukan eksplorasi di laut dandasar laut harus membawa garbage Record Book.Setiap pembuangan, atau pembakaran harus dicatat di dalam Garbage record book oleh perwira yang bertugas, tanggal pembakaran atau pembuangan ditulis, dan dengan bahasa Inggris, Spanyol dan Prancis dan ditanda tangani oleh nahkoda.Pencatatan pada waktu pembakaran atau pembuangan antara lain tanggal, waktu, posisi kapal, jenis sampah, perkiraan jumlah. Garbage record book harus disimpan diatas kapal disuatu tempat karena sewaktu - waktu dilakukan pemeriksaan Dokument ini harus disediakan untuk periode 2 tahun.

\section{Peran Awak Kapal}

Peran adalah suatu kompleks pengharapan manusia terhadap caranya individu harus bersikap dan berbuat dalam situasi tertentu yang berdasarkan status dan fungsi sosialnya, (Abu Achmadi ,1982) Menurut Soerjono Soekanto ( 2002: 243 ) peran adalah merupakan aspek dinamis kedudukan ( status ) apabila seseorang melaksanakan hak dan kewajibannya sesuai dengan kedudukannya, maka ia menjalankan suatu peranan. Di dalam Kamus Besar Bahasa Indonesia, peran adalah perangkat tingkah yang diharapkan dimiliki oleh orang yang berkedudukan dalam masyarakat. Berarti peran awak kapal adalah perangkat tingkah laku yaitu apabila 
awak kapal melaksanakan hak dan kewajibannya di kapal dalam kegiatan pencegahan pencemaran.

Menurut Undang - undang no 17 Tahun 2008 tentang pelayaran, awak kapal adalah orang yang bekerja atau diperkerjakan di atas kapal oleh pemilik atau operator kapal untuk melaksanakan tugas di atas kapal sesuai dengan jabatannya yang tercantum dalam sijil.Nakhoda adalah seorang dari awak kapal yang menjadi pimpinan umum diatas kapal serta mempunyai wewenang dan tanggungjawab tertentu sesuai dengan peraturan perundang - undangan yang berlaku. Perwira adalah mereka yang tercantum dalam daftar anak kapal kapal dan diberikan pangkat sebagai awak kapal. Anak Buah Kapal adalah awak kapal selain Nakhoda dan perwira/ pemimpin.

Di dalam Pasal 122 undang - undang no. 17 tahun2008 tentang pelayaran disebutkan bahwa Setiap pengoperasian kapal dan pelabuhan wajib memenuhi persyaratan keselamatan dan keamanan serta perlindungan lingkungan maritim.

Perlindungan lingkungan maritim yaitu kondisi terpenuhinya prosedur dan persyaratan pencegahan dan penanggulangan pencemaran dari kegiatan:

a. kepelabuhanan;

b. pengoperasian kapal;

c. pengangkutan limbah, bahan berbahaya, dan beracun di perairan;

d. pembuangan limbah di perairan; dan

e. penutuhan kapal.

Selain tugas dan tanggungjawab di atas kapal awak kapal berperan dalam kegiatan sehari - hari untuk perlindungan lingkungan maritime,selain dalam kegiatan operasional kapal setiap awak kapal mendapatkan peran ketika keadaan darurat untuk pencegahan pencemaran di laut yang tertuang dalam sijil darurat pencegahan pencemaran laut dari kapal.

\section{Pencegahan Pencemaran di Laut}

Menurut Kamus Besar Bahasa Indonesia ( 2007 ) adalah proses, cara, tindakan mencegah atau tindakan menahan agar sesuatu tidak terjadi .Dengan demikian pencegahan merupakan tindakan yang identik dengan perilaku.

Di dalam Pasal 1 butir 12 Undang - undang Nomor 23 Tahun 1997 tentang pengelolaan linkungan hidup "Pencemaran Lingkungan" adalah masuknya atau dimasukkannya makhluk hidup, zat, energy, dan komponen lain ke dalam lingkungan sehingga kualitas lingkungan turun sampai ke tingkat tertentu yang menyebabkan lingkungan hidup tidak berfungsi sesuai peruntukannya. Dalam penelitian ini berarti pencemaran laut adalah masuknya makhluk hidup, zat, energy, dan komponen lain ke dalam lingkungan lautan sehingga kualitas lingkungan di laut turun sampai ke tingkat tertentu yang menyebabkan lingkungan hidup tidak berfungsi sesuai peruntukannya.

Dalam kegiatan operasional kapal untuk kegiatan pengelolaan sampah untuk mencegah pencemaran di laut mengacu pada Undang - undang No. 17 tahun 2008 tentang pelayaran yaitu mengenai perlindungan lingkungan laut, undang - undang tentang lingkungan hidup dan regulasi internasional yang tertuang dalam Annex V Marpol 1973/1978 yaitu bagaimana pihak pemerintahan, pelabuhan dan kapal untuk menjamin terlaksananya perlindungan terhadap lingkungan laut. 


\section{METODE}

\section{Variabel Penelitian}

Variabel penelitian itu meliputi faktor- faktor yang berperanan dalam peristiwa yang akan diteliti. Pengukuran variable penelitian dilakukan dengan memberikan definisi - definisi operasional sebagai indikator penelitian dari masing - masing variabel untuk memudahkan peneliti dalam memilih kategori derajat tingkat penelitian yang sesuai dengan yang dirasakan responden.

Pada penelitian ini variabel penelitiannya terdiri dari :

1. Variabel independen (bebas)

Yaitu Pengelolaan sampah di kapal di kapal ( X1 ) dan peran awak kapal dalam pencegahan pencemaran ( X2 ).

a. Pengelolaan sampah di kapal (X1)

Pengelolaan sampah di kapal adalah kegiatan pemanfaatan dan pengendalian atas semua sumber daya manusia dan lainnya yang ada untuk mencapai tujuan supaya sampah tidak mencemari laut sesuai ketentuan nasional maupun Internasional.

Indikator - indikator faktor pengelolaan sampah di kapal pada penelitian ini meliputi :

a. Pelaksanaan perlindungan lingkungan laut di kapal

b. Pengelolan sampah sesuai ketentuan pembuangan sampah dari kapal sesuai Annex V Marpol 1973/1978

c. Pengelolaan sampah sesuai Garbage Management Plans

d. Garbage record Book

b. Peran Awak Kapal dalam Pencegahan Pencemaran ( X2 )

Peran awak kapal adalah perangkat tingkah laku yaitu apabila awak kapal melaksanakan hak dan kewajibannya di kapal dalam kegiatan pencegahan pencemaran yaitu peran dalam kegiatan pencegahan pencemaran di laut dari sampah kapal dalam kegiatan sehari - hari , dalam latihan , maupun dalam keadaan darurat pencegahan pencemaran di laut.

Indikator - indikator dalam penelitian ini terkait faktor peran awak kapal dalam pencegahan pencemaran oleh sampah dari kapal adalah :

a. Pengelolaan sampah oleh awak kapal dalam rutinitas sehari - hari di laut

b. Pengelolaan sampah oleh awak kapal ketika kapal sandar di pelabuhan

c. Peran awak kapal dalam sijil pencegahan pencemaran di laut

d. Evaluasi terhadap pelaksanaan pengelolaan sampah di kapal

2. Variabel Dependen ( tergantung )

Yaitu variabel yang fungsinya dipengaruhi oleh variabel lain karenanya juga sering disebut variabel yang dipengaruhi oleh variabel yang lain. Pada penelitian ini variabel dependent ( tergantung ) nya adalah :

\section{Pencegahan Pencemaran di Laut OLeh Kapal - kapal di Dermaga Pelabuhan Tanjung Perak Surabaya ( Y )}

Dalam kegiatan operasional kapal untuk kegiatan pengelolaan sampah untuk mencegah pencemaran di laut mengacu pada Undang - undang No. 17 tahun 2008 
tentang pelayaran yaitu mengenai perlindungan lingkungan laut, undang - undang tentang lingkungan hidup dan regulasi internasional yang tertuang dalam Annex V Marpol 1973/1978. Yaitu bagaimana pihak pemerintahan, pelabuhan dan kapal untuk menjamin terlaksananya perlindungan terhadap lingkungan laut.

Indikator - indikator penelitian mengenai faktor pencegahan pencemaran di laut oleh sampah dari kapal di pelabuhan Tanjung Perak Surabaya meliputi: Program Latihan

a. Fasilitas penampungan sampah di kapal

b. Peralatan pengelolaan sampah di kapal

c. Fasilitas Pembuangan sampah di pelabuhan

d. Monitoring dari management dan pemerintah

\section{Populasi Dan Sampel}

Populasi yang digunakan dalam penelitian ini adalah awak kapal yang kapal - kapalnya sandar di dermaga Tanjung Perak Surabaya sejumlah 100 ( seratus) responden.Peneliti mengambil sampel seluruh polpulasi yang diteliti, dalam penelitian ini menggunakan sensus yaitu semua populasi yang diteliti ( Sugiyono ,2013 : 78 ), yaitu berjumlah 100 responden.

\section{Metode Analisis}

Jawaban yang diperoleh dari responden dan sesuai dengan nilai variabel yang telah ditetapkan selanjutnya akan dianalisis dengan menggunakan alat bantu program komputer SPSS , Statistic 21,0. Dalam penelitian ini menggunakan metode kuantitatif .Analisis kuantitatif dilakukan untuk menggambarkan hubungan antara variabel dalam penelitian dengan menggunakan perhitungan statistik. Adapun tes ( uji ) statistik yang digunakan untuk menganalisis data adalah sebagai berikut .

\section{Uji Validitas dan Reliabilitas}

\section{a. Uji Validitas}

"Validitas adalah seberapa jauh alat dapat mengukur hal atau subyek yang ingin diukur ( Iqbal Hasan, 2004 ) ".Rumus korelasi yang digunakan untuk menghitung validitas yang terkenal adalah rumus korelasi product moment yaitu sebagai berikut:

$$
r=\frac{n \cdot \sum X Y-\left(\sum X\right)\left(\sum Y\right)}{\sqrt{\left(n \cdot \sum X^{2}-\left(\sum X\right)^{2}\right)\left(n \cdot \sum Y^{2}-\left(\sum Y\right)^{2}\right)}}
$$

Keterangan :

$\mathrm{r} \quad$ : Koefisien korelasi

n ; Jumlah sampel

$\mathrm{X} \quad$ : Variabel bebas

Y : Variabel terikat

b. Uji Reliabilitas 
"Reliabilitas artinya memiliki sifat dapat dipercaya. Suatu alat ukur dikatakan memiliki reliabilitas apabila dipergunakan berkali - kali oleh peneliti yang sama atau oleh peneliti yang lain tetap akan memberikan hasil yang sama. Jadi reliabilitas adalah seberapa jauh konsistensi alat ukur untuk dapat memberikan hasil yang sama dalam mengukur hal atau subyek yang sama ( Iqbal Hasan, 2004 ) ".Suatu konstruksi quitioner dikatakan reliabel jika nilai $(\alpha)$ lebih besar dari 0,6.

\section{Analisis Regresi Linear Berganda}

Analisis ini digunakan untuk menganalisis pengaruh antara variabel independen ( X ) yaitu Pengelolaan sampah di kapal ( X1 ) dan peran awak kapal ( $\mathrm{X} 2$ ) terhadap variabel dependen ( Y ) yaitu Pencegahan pencemaran di laut dari kapal .

Model penelitian yang digunakan pada penelitian adalah model Kutner, Nachtsheim dan Neter dalam Astriawati (2016, p.24)

$$
Y=a+b 1 . X 1+b 2 . X 2+\mu
$$

Keterangan :

Y : Pencegahan pencemaran di laut dari kapal

a : Konstanta

b1,b2 : Koefisien regresi berganda faktor penelitian

X1 : Faktor Pengelolaan sampah di kapal

X2 : Peran awak kapal

$\mu \quad$ : Variabel lain yang tidak terdeteksi

\section{HASIL DAN PEMBAHASAN}

\section{Uji Validitas}

Uji validitas dan reliabilitas dilakukan terlebih dahulu sebelum penelitian yang sebenarnya dilakukan,. Uji validitas dan reliabilitas dari jawaban 100 responden untuk menentukan pertanyaan-pertanyaan kuesioner mana yang diinyatakan valid dan kehandalan dari alat ukur konsep variabel tersebut.Kevalidan suatu item pertanyaan diukur dengan pengujian validitas. Untuk menguji valid atau tidaknya pertanyaan yang akan diajukan dengan membandingkan nilai $\mathrm{r}$ hitung ( corrected item total correlation dibandingkan dengan nilai $r$ table dengan tingkat kepercayaan $95 \%(0,05)$ yaitu :

i. Item jawaban valid bila $r$ hitung $>r$ tabel

ii. Item jawaban tidak valid bila $r$ hitung $<\mathrm{r}$ tabel

Berdasarkan hasil perhitungan dengan alat bantu SPSS ver.21.0 diperoleh nilai Corrected item total correlation ( $\mathrm{r}$ hitung) dan ke 12 ( dua belas ) pertanyaan dapat disajikan sebagai berikut :

Tabel 2. Hasil Uji Validitas

\begin{tabular}{|l|c|c|c|}
\hline \multicolumn{1}{|c|}{ Variabel Penelitian } & r hitung & r tabel & Kesimpulan \\
\hline Pengelolaan sampah di kapal & & & \\
Jawaban responden & & & \\
Pertanyaan no. 1 & 0,733 & 0,197 & Valid \\
Pertanyaan no. 2 & 0,805 & 0,197 & Valid \\
Pertanyaan no. 3 & 0,757 & 0,197 & Valid \\
\hline
\end{tabular}




\begin{tabular}{|l|c|c|c|}
\hline Pertanyaan no. 4 & 0.324 & 0.197 & valid \\
Peran awak kapal & & & \\
Jawaban responden & 0,513 & 0,197 & Valid \\
Pertanyaan no. 1 & 0,694 & 0,197 & Valid \\
Pertanyaan no. 2 & 0,748 & 0,197 & Valid \\
Pertanyaan no. 3 & 0,294 & 0,197 & Valid \\
Pertanyaan no. 4 & & & \\
Pencegahan pencemaran & & & \\
Jawaban responden & 0,799 & 0,197 & Valid \\
Pertanyaan no. 1 & 0,801 & 0,197 & Valid \\
Pertanyaan no. 2 & 0,701 & 0,197 & Valid \\
Pertanyaan no. 3 & 0,575 & 0,197 & Valid \\
Pertanyaan no. 4 & & & \\
\hline
\end{tabular}

Sumber: Hasil Uji Validitas ,2019

Berdasarkan tabel 2 dapat di ketahui bahwa hampir seluruh butir jawaban responden valid dan dapat digunakan dalam penelitian karena memiliki nilai $r$ hitung > $r$ tabel $(0,197)$.

\section{Uji Reliabilitas}

Digunakan untuk menguji sejauh mana keandalan suatu alat pengukur untuk dapat digunakan lagi dalam penelitan yang sama. Dengan menggunakan rumus alpha maka didapat koefisien reliabilitas untuk masing-masing indikator yang diringkas pada tabel 3 berikut ini :

Tabel 3. Hasil uji reliabel

\begin{tabular}{|c|l|c|c|}
\hline No & \multicolumn{1}{|c|}{ Variabel } & Alpha & Kesimpulan \\
& & & \\
\hline 1. & Pengelolaan sampah di kapal (X1) & 0,778 & Reliabel \\
2. & Peran awak kapal ( X2) & 0,696 & Reliabel \\
3. & Pencegahan Pencemaran di laut dari & 0,705 & Reliabel \\
& kapal & & \\
\hline
\end{tabular}

Sumber : Hasil uji Reliabel,2019

Dari hasil diatas dapat dijelaskan bahwa variabel-variabel dalam penelitian ini andal atau reliabel karena memiliki koefisien alpha yang lebih besar dari 0,60.

\section{Analisis Regresi Linier Berganda}

Persamaan garis regresi berganda adalah untuk mengetahui pengaruh variabel bebas (pengelolaan sampah di kapal) terhadap variabel terikat (peran awak kapal) dan hasil regresi tersebut dapat diringkas pada tabel 4 diperoleh persamaan garis regresi berganda, yaitu : 
Tabel 4. Ringkasan Hasil Perhitungan Regresi

\begin{tabular}{|l|r|r|l|l|}
\hline Variabel & Koefisien & $\mathrm{t}-$ rasio & $\begin{array}{l}\text { Prog - } \\
\text { sig }\end{array}$ & Kesimpulan \\
\hline Konstan & 3,563 & 2,208 & 0,030 & Signifikan \\
Pengelolaan sampah di kapal & 0,486 & 5,103 & 0,000 & $\begin{array}{l}\text { Signifikan } \\
\text { Peran Awak Kapal }\end{array}$ \\
& 0,315 & 2,916 & 0,004 & Signifikan \\
\hline & & & \\
F- hitung & 39,328 & (Prob - sig $=0,000)$ \\
$\mathrm{n}$ & 100 & \\
\hline
\end{tabular}

Sumber : Hasil perhitungan regresi ,2019 berikut:

Berdasarkan tabel perhitungan regresi diatas diperoleh persamaan sebagai

$\mathrm{Y}=3,563+0,486 \mathrm{X}_{1}+0,315 \mathrm{X}_{2}+\mu$

a. Koefisien regresi $\left(\mathrm{X}_{1}\right)$ pengelolaan sampah di kapal sebesar 0,486

pengelolaan sampah dikapal berpengaruh positif terhadap pencegahan

pencemaran di laut dari kapal, hal ini dapat dipertegas lagi jika variabel pengelolaan sampah di kapal ditingkatkan sebesar $100 \%$, sedangkan variabel lain dianggap konstan maka akan berpengaruh terhadap peningkatan penceghan pencemaran dari kapal sebesar 48,6\%

b. Koefisien regresi $\left(\mathrm{X}_{2}\right)$ Peran awak kapal sebesar 0,315

Peran Awak Kapal berperigaruh positif terhadap pencegahan pencemaran dari kapal , hal ini dapat dipertegas lagi jika variabel latihan peran awak kapal ditingkatkan sebesar $100 \%$, sedangkan variabel lain dianggap konstan maka akan berpengaruh terhadap peningkatan pencegahan pencemaran dari kapal sebesar $31,5 \%$.

\section{Uji Hipotesis}

a. Uji t

Uji t (uji parsial) digunakan untuk menganalisis apakah ada pengaruh antara variabel bebas (pengelolaan sampah di kapal, latihan peran awak kapal terhadap variabel terikat (pencegahan pencemaran dari kapal) secara parsial. yang mana sebelum di lakukan pengujian hipotesis dapat dilakukan sebagai berikut:

Hipotesis yang diajukan

Ho : Tidak ada pengaruh yang positif dan signifikan antara pengelolaan sampah di kapal, peran awak kapal secara terhadap pencegahan pencemaran dari kapal dari kapal

Ha : Ada pengaruh yang positif dan signifikan antara pengelolaan sampah di kapal, Peran awak kapal secara parsial terhadap pencegahan pencemaran dari kapal dari kapal.

Sedang untuk mengetahui hasil dan uji t ini dapat dilihat beberapa ketentuan dibawah ini:

1. Apabila t hitung $>\mathrm{t}$ tabel maka Ho ditolak

Majalah Ilmiah Bahari Jogja 82 | http://jurnal.amy.ac.id/index.php/MIBJ/ 
Apabila t hitung $<\mathrm{t}$ tabel maka Ho diterima

2. Tingkat $\alpha=0,05$

3. Uji dua sisi (two tail test)

4. $\mathrm{t}$ tabel $=1,987$

a. Uji Hipotesis antara Variabel pengelolaan sampah di kapal terhadap pencegahan pencemaran dari kapal dari kapal.

Dari hasil perhitungan regresi diperoleh t hitung $=5,105$

t hitung > t table yaitu 5,105> 1,987 berarti Ho di tolak dan Ha dterima yaitu ada pengaruh yang positif dan signifikan antara pengelolan sampah di kapal terhadap pencegahan pencemaran dari kapal dari kapal.

b. Uji Hipotesis antara variabel peran awak kapal terhadap pencegahan pencemaran dari kapal.

Dari perhitungan regresi diperoleh t hitung $=2,916$

t hitung > t table 2,916 >1,987 berarti Ho di tolak dan Ha diterima yaitu ada pengaruh yang positif dan signifikan antara peran awak kapal terhadap

b. Uji F pencegahan pencemaran dari kapal dari kapal.

Uji $\mathrm{F}$ digunakan untuk menganalisis apakah variabel bebas (pengelolaan sampah di kapal, peran awak kapal) secara simultan (bersama-sama) mempunyai pengaruh signifikan terhadap variabel terikat (pencegahan pencemaran dari kapal dari kapal )

a. Hipotesis yang diajukan

Ho : Tidak ada pengaruh secara simultan antara variabel bebas (pengelolaan sampah di kapal, peran awak kapal) terhadap variabel terikat ( pencegahan pencemaran dari kapal dari kapal)

Ha : Ada pengaruh secara simultan variabel bebas (pengelolaan sampah di kapal,peran awak kapal ) terhadap variabel terikat (pencegahan pencemaran dari kapal ).

b. Tingkat $\alpha=0,05$

c. $\mathrm{F}$ tabel $=1,37$

d. Dari hasil uji regresi diperoleh F hitung $=39,328$

F hitung > Ftabel yaitu 39,328 >1,37 hal ini berati Ho ditolak dan Ha diterima yaitu ada pengaruh secara simultan variabel bebas pengelolaan sampah di kapal dan peran awak kapal terhadap pencegahan pencemaran dari kapal.

\section{SIMPULAN}

Berdasarkan hasil perhitungan secara kuantitatif dengan program SPSS versi 21 diperoleh dengan analisis regresi diperoleh :

a. Pengelolaan sampah dikapal dengan indikator (perlindungan lingkungan laut, pengelolaan sampah sesuai dengan annex V MARPOL 1973/1978, pengelolaan sampah sesuai Garbage management Plan dan Garbage Record Book ) berpengaruh terhadap peningkatan pencegahan pencemaran dari kapal sebesar 48,6 \%. Oleh karena itu apabila pihak managemen kapal / perusahaan

Majalah Ilmiah Bahari Jogja 83 | http://jurnal.amy.ac.id/index.php/MIBJ/ 
pelayaran yang kapal - kapalnya sandar di Tanjung Perak Surabaya lebih meningkatkan pengelolaan sampah di kapal sesuai Annex V MARPOL 1973/1978, sesuai garbage management plan dan garbage record book maka kegiatan pencegahan pencemaran laut dari kapal juga akan lebih meningkat.

b. Peran Awak Kapal dengan indikator (pengelolaan sampah oleh awak kapal dalam rutinitas sehari hari, ketika kapal sandar di dermaga / pelabuhan, peran awak kapal dalam sijil darurat pencegahan pencemaran, evaluasi pengelolaan sampah ) berpengaruh terhadap peningkatan pencegahan pencemaran dari kapal sebesar 31,5\%. Sehingga apabila awak kapal memiliki kesadaran dalam pencegahan pencemaran dari sampah kapal baik itu ketika di pelabuhan maupun di laut lepas ataupun ketika ada pengawasan dari pihak managemen kapal, pemerintah atupun tidak dalam pengelolaan sampah dalam rutinitas sehari - hari di kapal, maka pencegahan penceran laut dari kapal juga meningkat.Oleh karena itu pihak manjemen kapal, pemerintah sebaiknya meningkatkan kesadaran dan pengawasan terhadap awak kapal dalam meningkatkan kepedulian lingkungan laut dari sampah.

c. Dari uji $\mathrm{t}$, variable pengelolaan sampah di kapal terhadap pencegahan pencemaran dari kapal diperoleh t hitung $>\mathrm{t}$ table yaitu 5,105 > 1,987 berarti ada pengaruh yang positif dan signifikan antara pengelolan sampah di kapal terhadap pencegahan pencemaran dari kapal . Dari uji t variable peran awak kapal terhadap pencegahan pencemaran dari kapal $\mathrm{t}$ hitung > t table 2,916 $>1,987$ berarti ada pengaruh yang positif dan signifikan antara peran awak kapal terhadap pencegahan pencemaran dari kapal dari kapal.

d. F hitung $>$ Ftabel yaitu 39,328 >1,37 hal ini berati ada pengaruh secara simultan variabel bebas pengelolaan sampah di kapal dan peran awak kapal terhadap pencegahan pencemaran dari kapal. Oleh karena itu pihak manajemen kapal yang kapal- kapalnya sandar di Tanjung Perak Surabaya pada khususnya, pihak perusahaan pelayaran dan pemerintah sebaiknya meningkatkan manajemen pengelolaan sampah, fasilitas / peralatan pengelolaan sampah di kapal dan peran awak kapal dalam upaya meningkatkan pencegahan pencemaran laut dari kapal.

\section{DAFTAR PUSTAKA}

Astriawati, N. (2016). Penerapan Analisis Regresi Linier Berganda. Bahari Jogja, XIV, 22-37. Retrieved from

http://jurnal.amy.ac.id/index.php/MIBJ/article/view/90/89

IMO, ( 2002 ). MARPOL 73/78 Consolidated Edition. London.

Iqbal Hasan. (2002). Metodologi dan Aplikasinya. Jakarta: Ghalia.

Mirdin Ahmad. (2016). Analisis Penanganan Sampah di Kapal untuk Mencegah Polusi di Laut, Jurnal Bung,Sistem Informasi Jurnal Ilmiah vol 10 No.2 Agustus 2015.

Purwaningsih.Wiwik.(2007). Strategi Pengelolaan Sampah Pada Kapal Penumpang tipe PAX 2000. Digital Library. Institut Teknologi Sepuluh Nopember.

Sugiyono.( 2013). Metode penelitian Bisnis. Bandung: Alfabeta. 
Undang - Undang Republik Indonesia Nomer 17 Tahun 2008 Tentang Pelayaran. Yayasan Kesejahteraan Keluarga Karyawan Perhubungan Laut "Sekar Laut “ (1983). Himpunan Ketentuan- Ketentuan International Tentang Pencegahan Pencemaran Laut Dari Kapal. Jakarta . 